\title{
On a Villanelle by Elizabeth Bishop - David Shapiro
}

To Paul Silverman

THE NEW Y ORK ER M A G A Z I N E published a masterpiece on April 26, 1976. Elizabeth Bishop's “One Art," later reproduced in her Geography III, is a convincingly drastic approach to the archaic French form. It shows what drabness may do for an all-too-golden repetitive form. It is superior to the maudlin manias of Thomas, finer than the cerebrations of Empson and still severe, and takes its place along with those of Auden, James Schuyler, and a few other premonitory practitioners' specimen stanzas.

The title is "One Art," and it identifies for us the integrity and lack of integrity that remain the polarizing tensions of the poem. It is indeed a poem of explicit art, of many-minded cunningness. The poem reminds us, as Freud does in his chapters upon the theme of forgetting in The Psychopathology of Everyday Life, that the most buried life corresponds in its dynamic aspects to writing, to expression. The poem is necessarily selfreferential and self-reflexive whilst it never gives up its bitter burden of referentiality. The art of losing seems a mere theme, but it is also the central and active theme of themelessness, affording such a space of absence to the poem. The title is reserved and masterful. In a poem which conceives of mastery in the most negatively thrilling terms, it stands as a Keatsian "lone star" of hermitage over the poem. The title is an unadorned handle and forgets nothing.

A villanelle may be said to be the classic form of repetition and persistence. Like Kierkegaard, Bishop broods about the possible repetitions possible upon this mortal earth. She is part of the "dreaming tribe" Keats brooded about and nearly deposes in his "Fall of Hyperion" and she persists in brooding. The poem is both an homage to poetry, a defense of poetry, and a terrifying lament about the weaknesses of poetry in relation to mortalia that touch us in the Virgilian sense. Each repetition furnishes a new twist of suffering. Rather than producing a stream of repetitions to remind us of voice or consciousness in Stein's explicit meanderings, she composes and decomposes with repetition and persistence to give us a very palpable thickness (in Jakobson's senses) of attention.

The poem is filled with palpable dissonances of off-rhymes that link Bishop with the tradition of orality, desire, and dissonance, in Dickinson and Moore: fluster/master; gesture/master. These dissonances each lead to the incongruous congruent rhyme of master and disaster. It IS disaster that is the large fate of the master. As Heidegger has it of Nietzsche, so Bishop of herself, the topoi are the circle and suffering. The poem is a circle from which we cannot escape anymore than Borges can escape from Odin's disk in his phantasmal story. The poem and its archaistic form are themselves a fine and almost comical fate. One modulates from dissonance to dissonance, as in Charles Rosen's sense of the "classical style," too often perceived as a 
constant turning towards harmonies. The harmonies are small interpolations in a prose world of suffering.

Bishop never speaks too much. Montale has said, "The false poet speaks." Her poetry is not the falsely deceived one of utterance. But her diction is properly humiliated and low in a Wordsworthian sense; she never rises too high or aspires too magically, though the whole is sublimated magic. She begins with art and ends with art, "The art of losing . ... (Write it!)" and so the whole poem is an essay as much as it is, in Ong's slightly too mystical and logocentric sense, a cry.

Bishop is involved with difficulty. The art is one of making an absence palpable, and she draws attention to her poem constantly in the way the Russian formalists never tired of presenting. She is, moreover, a presentationalist; and thus, she is even more filled with pathos at the theme of presenting, in Ashbery's phrase, a fundamental absence. Within the poem, she offers advice, but as Frost does in "Provide, Provide," as a battered self making small invectives out of the world's demands. When she asks us to "Lose something every day," we understand this as a collapsed soliloquy and, along with Jarrell on Frost, we are most moved by her very lack of confidence in the injunction. The whole poem does throughout make a confidence out of a failure of Mnemosyne. Since poetry is memory, the art of losing is a form of anti-poetry which she transmutes most naturally into the poem. To forget is in a Freudian sense even more a symptom and displacement and metaphor than a memory. Forgetting traces our own shapes. It is Bishop's triumph to write it out in such disappearing ink.

Bishop is concerned with mastery, self-mastery too as a metaphor for mastery within form, not over and above form. She plays upon the versions of the word "loss" too with the erotic playfulness of Andrewes in those sermons that so charmed Eliot. The whole poem is one of drastic advice to the ephebe, as Stevens reminds us that writer and reader are in an essential Socratic relationship of rapport and disrupted rapport. The poem reproduces something of the hysteria that precedes the desire for mastery, just as Empson has noted that the negatives in Keats' "Ode to Melancholy" remind us how much the poet was tempted to go there. ". . . practice losing farther, losing faster," writes Bishop, and by the spatial and temporal modifiers she reminds us that we are going into the hallucinatory modality of the ephebe's first negative way.

Indeed, the poem as sacrifice is part of Bishop's puritanical traditio, and the verbs are verbs of sacrifice. We must lose, we must offer, but along with Kierkegaardian man we must never ask for unhappiness, but wish for more. Every time the poem names some thing, it is not a public thing, but a private care or treasure, or if public, like two cities, the public seen privately and treasured as a dwelling. Like Heidegger, she is the homeless one seeking a home and understanding that to dwell is to be, to be is to build. The little villanelle is a "mirror on which to dwell," a building to inhabit, an empti- 
ness built upon emptiness. We are reminded always of her constructivist bias, her architectural gifts, as it were, as she shatters the form and fuses it simultaneously.

A reading of the poem shows it as a grammatology in Derrida's sense, a scene of writing given to us as an alysis of writing itself, with all the whims of an almost absolute negativity. What one must remember is to write. What one must remember is that one will forget everything else, that one will lose everything but the faculty to write. Writing is not negative in relation to sound or to voice. Writing precedes everything in the most unexpected way; without the art, there is nothing. In the writing there is a beginning.

Thus, we are watching an almost scientiftic unfolding of the magic writing pad. Bishop is a writer dedicated to the fitting proportions of consciousness and unconsciousness. She has separated herself, like Auden, from the French tradition of automatism and surrealism. Yet both no doubt have undergone an interpenetration with that system of thought and thoughtlessness. One thinks of Auden's debt to St.-John Perse and Bishop's own relations to Valery and even Laforgue through Auden and Eliot. She is constantly warning us, and warning us against bétise and sottises, but her poetry therefore and nevertheless bespeaks an extraordinary interest in the buried life and the drunken boat of possibility. "So many things seem filled with the intent/to be lost" is a phrase that seems to have wandered out of the haunted wood of Baudelaire's "Correspondences." We correspond and respond indeed in a haunted universe to objects and subjects that seem to have no other object but to haunt us. Bishop is all too often in the pays des merveilles.

Throughout the poem, one imagines a certain congruence between text and psyche, until what we are astonished by is that this has indeed become a text of transgression and madness. The poem has not at its coda but at its very non-Aristotelian heart the art of losing oneself, the art of losing a self, the art of almost losing a text, the art of losing the shifty shifter "you." Bishop is involved with the dangerous theme of solipsism and she shows us the horror of private language in her parenthetical asides that are a tribute to her reticence. "(the joking voice, a gesture/I love.)" She tries to keep these parentheses as Proustian delays, as suspenses, as adornments, but what they seem to come to mean are multiplicities, transversals, as argued recently concerning Proust and in relation to Deleuze's meditations upon the multiplicities of desires in the writings of that master. At any rate, her parentheses function paradoxically as breakdowns of the syntax and as rhetorical abundance and advantage.

What is appalling in the poem is that one comes to see indeed the facility of mortality, the easiness of oblivion, of mastery. The art of remembering is hard; the art of forgetting is the natural one of any ephebe. Of course, the irony throughout is one which a Kierkegaardian critique might depose. But 
one is not able to use here any ethical critique as a check against Bishop, just as Bloom argues elsewhere that the ethical will not check Keats unless it comes from a poet who equally honors the earth.

This is a poem that is not tied down to things nor morbidly dependent upon the earth, though it is filled with a tension created by the feeling-tone of dependency and passivity and self-doubt, recently called by no less a journalistic purveyor of clichés than "The New York Times" the attribute of an addict. Like Emily Dickinson, Bishop is indeed part of the tradition addicted to possibility, "a fairer house than prose." The poem, however, must be argued as abstract, a poem of sullen surfaces, a poem of shattered facets. It is a villanelle, not because as Graves would have it as regards the sonnet, Bishop wandered into the sonnet and woke up when it was half finished. It is a villanelle, that most plotted and formal of probabilistic gardens, because suffering could demand no other strategy than the abstract choreography of the villanelle. It is not a dance of tensions along Cleanth Brooksian lines, it is not a well-made urn, but a kind of well-wrought emptiness. It begins with the abstract statement "The art of losing isn't hard to master" and it concludes with the force of syllogism: "It's evident/the art of losing's not too hard to master." The little difference of the colloquial "not too hard" is all the difference in the world. It's not too hard, one reads, and why this significant difference?

The poem is about falling away, disaster, and as we fall towards the conclusion we realise that poetry itself affords us a mastery. While we cannot handle anything within the poem but imaginary door keys and uncomfortable or anguishing hours, within the poem we may keep these things by naming them.

Throughout this poem there is neither unmastered irony nor mastered irony. There is the presentation of the process of trying to master irony. Mastering/Irony is the present tense of this poem. The poem is a series of brilliantly tragic asides to the ephebe who is still oneself, and to the text of the eternal ephebe. The poem is not the poem of an aesthete but it is the bitter novel of the self-poisoned one. The poet like Hyperion has lost not just a realm but a self, and a self that was a realm and a you that guaranteed the poignant sweetness of this realm. All this is gone before the poem starts.

The disaster of the poem is a self-reflexive one, like the self-reflexive breakdown of syntax at the end: "the art of losing's not too hard to master/though it may look like (Write it!) like disaster." The immense repetition at the end bespeaks all trouble, all dreads, all stutterings that Freud said speak of mental contradiction. Here is the level of ambiguity Empson shied away from when he spoke of mental contradiction in the poetics of Gertrude Stein. The disaster is seen and grasped in the speaking music of the poem. Beyond the appearance of mastery is a Goethean statute of limitations. The poem is perceived as an erotic transgression that commits the poet to the poem. In the imaginary, in the construct, is a poignant 
redemption that redeems all losing whilst forgetting nothing: "(Write it!)" It is a poetry of parenthesis and pathos, of exclamation and the exaltations of falling.

Elizabeth Bishop is strong enough, and not necessarily in Harold Bloom's sense, to accept the canonic and the arbitrary and the given. She accepts the given of the form in the way that Jasper Johns accepts the dark given of the design of the American flag. There is nothing more arbitrary and almost stupidly arbitrary than the villanelle. Whitehead says that tragedy and science grew hand in hand. We may be killed by rules that loom out of the dark; they make us and mar us, not the other way around. In such a way, the more we discover the invisible rules of form the more we doubt and yet insure our only form of human mastery in self-encouraged, self-acknowledged Socratic failure. To write poetry is to die, as much as to philosophize is to learn how to die. This little poem is a little death, as erotic, as vital as any death, as filled with suffering and as vast as a glimpse of a new continent. It is a glimpse of the oldest continent. It is no longer a travel poem in any easy exotic way; it is not a translation from any Portuguese but the psyche. "There is no frigate like a book." Just as Mallarmé brooded on the other, the burnt breast of the old Amazon, Bishop broods upon the other, the text, the furthest and the fastest text. The funniest rhymes (lastor/master) remind us of the friction of experience within the Imaginary. The changes within the poem are vital admissions ("I miss them, but it wasn't a disaster") but never melodramas of the confessional. It is the anti-theatrical, a wordless theatre played between the stanzas. The poem has its ethos against any easy deception "I shan't have lied." Within its opacities, its labyrinths, the poem overcomes all obstacles to achieve a final pathos.

Mastery must always be mastery of disaster. There is no need for mastery except on the horizon of dread and death. All of the things lost within the villanelle are indeed metaphors for this death, this final divorcer, in Keats' great phrase. While writing itself seems like a separation, it is dedicated to the most final of separations. The poem achieves a mastery within a pathos in the classical framework of Aeschylus: pathei mathos. Here wisdom is not wrought from suffering alone but from forgetting, too. Oblivion is a temptation and Elizabeth Bishop puts her cunning against oblivion. She says, wittily, Are you afraid to lose? afraid to forget? afraid to die? Then, with Frankl and his marvellous theories of paradoxical intention, she murmurs, Then lose, then lose door keys, lose hours, lose everything, and then you will become a master. Hard advice, but "how witty's ruine." 